\title{
CALDERÓN'S AMBIGUITY WITH RESPECT TO THE MORISCOS IN EL TUZANÍ DE LA ALPUJARRA
}

\author{
Brent W. Devos \\ The University of Lethbridge \\ [Anuario calderoniano (ISSN: 1888-8046), 2, 2009, pp. 111-127]
}

El Tuzaní de la Alpujarra by Pedro Calderón de la Barca is a tragic love story set against the backdrop of a civil war, specifically the Morisco rebellion that took place in the province of Granada between 1568 and 1571. The uprising was touched off, among other things, by the enactment in 1567 of a proclamation by Phillip II that prohibited all expressions of Morisco culture. The rebellion saw three years of bloodshed and was finally brutally put down by Phillip II's half brother, don Juan de Austria. It should come as no surprise, then, that there is an abundance violence in this play. In addition to the standard skirmish violence of war, there is wholesale massacre, individual murder, blood vengeance, regicide and, of course - no Calderón play would be complete without them- duels of honor.

But the violence I will focus on here did not, in theory at least, involve bloodshed, although it contributed, both in Calderón's play and historically, to the rebellion. I am referring to the campaign of ethnocide, of mandatory assimilation carried out against the Moriscos, 
beginning with the forced conversions of 1502 and culminating in the edicts of Phillip II. This project failed utterly, and the Morisco rebellion served to underline for old Christians what they had already believed to be true: that the Moriscos were unassimilatable, duplicitous, conspiratorial and false Christians. In short they were considered a danger to Spain's political and religious unity as well as to its internal security ${ }^{1}$. This perception only worsened with time, and led to the expulsion of the Moriscos from Spain between1609 and 1614.

Yet, critical studies to date of El Tuzaní de la Alpujarra have by and large interpreted Calderón's treatment of the rebel Moriscos as sympathetic. Alan A. Parker states that the author of El Tuzaní was a man "who was sensitive to the rights and sufferings of minority peoples» ${ }^{2}$, an opinion shared almost verbatim by Margaret Wilson ${ }^{3}$. José Miguel Caso González insists that in El Tuzaní "Calderón ha manifestado su oposición a la política oficial, a las tendencias y usos sociales de su época y a una concepción racista de la sociedad de su tiempo. Y ha defendido la dignidad caballeresca y genealógica de los moriscos bautizados» ${ }^{4}$. For his part, José Alcalá Zamora has indicated that in El Tuzaní we see «el interés y benevolencia de Calderón hacia los medios culturales extraños y los grupos marginados ${ }^{5}$.

We may ask then, with Margaret Greer, «Why would Calderón (famous for his service to the Catholic faith in his autos sacramentales long before he was ordained a priest in 1651) write a work that from its first lines conveys sympathy for a rebellious Granadine Morisco population, decades after their final expulsion from Spain between 1609 and 1614?». The simple answer, I submit, is that he didn't. I will argue here that when the play is considered in the political and ideological and theatrical context of the 1630's, the result is ideologically ambiguous, rather than sympathetic. I will focus only on the first part of the first act, as it is here that the Moriscos are characterized and sources of the conflict are introduced.

One of principle supports for the «sympathetic reading» of $E l$ Tuzani de la Alpujarra is the portrayal of the Morisco characters ver-

\footnotetext{
${ }^{1}$ Domínguez Ortiz, 1978, pp.163-164, 204.

2 Parker, 1988, p. 318.

${ }^{3}$ Wilson, 1984, p. 425.

${ }^{4}$ Caso González, 1983, p. 402.

5 Alcalá Zamora, 1981, p. 351.
} 
sus the old Christian characters. José Alcalá Zamora has stated, for example, that «la simpatía del dramaturgo se inclina ostensiblemente hacia la causa y los personajes moriscos, tratados con delicadeza y emoción, en contraste con los rasgos altaneros e intransigentes con que se caracteriza a los representantes de la cristiandad vieja» ${ }^{6}$.

The argument that Calderón portrays the Moriscos in a positive light and old Christians in a negative light depends, in my view, on two things: 1) selective attribution of authorial perspective and 2) ideological anachronism.

By selective attribution I refer to the assertion that the ideas expressed in the dialogue of certain characters reflect the opinion of the playwright. With respect to this, it is worth reiterating the obvious: drama does not have a narrator. In drama the ideological standpoint of the playwright is illusive. If indeed it is identifiable, must be gleaned from the meaning generated by the interplay between words, actions, staging and the cultural context in which the play is written and performed. In drama, when two characters voice opposite opinions, we cannot arbitrarily insist that the view of one or the other character represents that of the playwright; although the temptation to do so may be strong, particularly when the opinion expressed by a given character corresponds with our own.

With respect to ideological anachronism it is again, worth restating the obvious. To read El Tuzani de la Alpujarra in a way that is fair to its original context, we have to try to set aside our $21^{\text {st }}$ century perspective and attempt to reconstruct, to the extent that this is possible, the perspective, the presuppositions of a Spanish audience in the $1630 \mathrm{~s}^{7}$. Careful then to avoid ideological anachronism and selective attribution, let's attempt to take a fresh look at the play.

The opening scene of the play is important to the arguments in favor of the sympathetic reading. So let us begin there. Briefly, in the opening scene a group of Moriscos gathers in secret to celebrate a

${ }^{6}$ Alcalá Zamora, 2000, p. 296.

7 The frequently repeated date of 1633 is based on the mistaken attribution of a play by Pérez Montalbán, Más puede amor que la muerte, to Calderón. Nevertheless, there is other evidence to suggest that the play was written in the early 1630 s. See Devos, 2007, pp. 7-23. 
zambra or Morisco dance. The celebration is interrupted by a loud banging on the door.

Margaret Wilson gives this assessment of the play's beginning:

The play begins, as the revolt did, with the fiercely repressive [legislation] issued by Phillip II in 1567, forbidding the Moriscos the use of their own language, their ablutions, their traditional festivities and national dress. [Calderón] opens his play by showing the Moriscos' reactions to it, thus directing the audiences sympathies towards them from the start» ${ }^{8}$.

For her part Margaret Greer explains the process of eliciting sympathy in the opening scene in terms of psychological violation:

With the first words of the play, Cadís question, «¿Están cerradas las puertas?». Calderón opens the drama by evoking the intimate space of a house, the space of our human identifications — and of our primordial fears, one of which is the fear of seeing that intimate space invaded. The actors' attire, specified in Calderón's first stage direction, has already signaled wordlessly that it is a morisco residence. [...] the invaders they fear are Christian?.

Let's take a close look at this scene, starting with the opening stage direction: «Salen todos los moriscos que pudieren, vestidos a la morisca, jaquetillas y calzones, y las moriscas en jubones blancos, con instrumentos, Cadí y Alcuzcuz». This opening stage direction is unusual because it gives details about the Morisco costumes. Moorish and Morisco characters appear in countless comedias. Yet a search through the hundreds of comedias transcribed in Chadwick-Healey's TESO database reveals that in almost every case, the costume of the Moorish or the Morisco characters is described simply as «moro» or «de morisco» or «a lo moro» ${ }^{10}$.

${ }^{8}$ Wilson, 1984, p. 419.

9 Greer, 2006, p. 119.

${ }^{10}$ Comedia texts, dictionaries and costume inventories from the seventeenth century do not distinguish meaningfully distinction between "morisco» and «moro» costumes. The text of El Tuzaní is no exception in this regard, as may be seen in the following stage direction: «Sale[n] MALEC [y CADÍ] Habla[n], hincadas las rodillas, a VÁLOR, y a una puerta se queda D. ÁLVARO de moro y D.a CLARA, morisca, a 
The explanation for the lack of detail regarding the nature of the morisco costume is simply that the Autores de comedias, didn't need to be told what a Moor or Morisco was supposed to look like. Costumes for the various social types were conventionalized and each company had a basic wardrobe of standard costume pieces for standard roles (galán, dama, soldado, bandolero, moro, etc.) ${ }^{11}$. In the relatively rare cases where details are given regarding costumes, the purpose was usually to indicate something distinctive about the costume or its use on stage; perhaps a state of undress, a specific color or a deviation from the conventional costume ${ }^{12}$.

Since the play texts themselves give little information about what comprised Moorish or Morisco costumes, one has to consult theatrical wardrobe inventories from the period. These indicate that the conventional costume for the Moor or Morisco consisted of a marlota (a hip length loose fitting tunic), and pair of balons, a kind of balloon pants, all covered by an aljuba or ropón, which was a long loose fitting tunic $^{13}$. The jaquetillas, calzones and jubones blancos mentioned in the opening stage direction of El Tuzaní do not appear in descriptions of Moorish or Morisco costumes. On the contrary, according to Evangelina Rodríguez Cuadros, la jaquetilla, calzones for men and white jubones for women were the conventional costume used in the teatro breve to represent black Africans ${ }^{14}$. The black Africans who resided in Spain in Calderón's time were almost exclusively slaves ${ }^{15}$. So when the Moriscos took to the stage at the beginning of El Tuzani de la Alpujarra they wore conventional "a la morisca» costumes altered to suggest that they were of African origin and that they had the social status of slaves. This is born out in subsequent dialogue that refers in several places to the Moriscos as African (vv. 17, 58, 77, 94, 107, 176, 916, 938 y 2209) and to their suffering slavery and captivity in Spain.

otra» (Unless otherwise noted, all quotes from El Tuzaní de la Alpujarra are from my edition). In the Vera Tassis edition of Amar después de la muerte, the same stage direction reads: «a los lados del / paño salen Don Álvaro, y Doña Clara, / en traje de Moros», Calderón, Comedias, vol. XVIII Novena parte de Comedias, p. 259.

${ }^{11}$ Ruano de la Haza, 2000, pp. 79-84.

12 Ruano de la Haza, 2000, pp. 90-92.

13 Esquerdo, 1978, pp. 57, 84, 450.

14 Rodríguez Cuadros, 2000, pp. 36, 125.

15 Ulloa Cisneros, 1979, p. 322. 
Later in this first scene, for example, the Moriscos sing a song in which they lament the fact that they live "en triste cautiverio» (v. 15). A short while later, Malec agrees that the moriscos are «humildes, / gente abatida y esclava» (vv. 136-137). And at the end of the scene, Malec, inciting the Moriscos to rebellion, exclaims: «Ea, valientes moriscos, / noble reliquia africana, / los cristianos solamente / haceros esclavos tratan!» (vv. 176-179) and «Elegid una cabeza / de la ilustre sangre clara / de vuestros Abenhumeyes, / pues hay en Castilla tantas, / y haceos señores de esclavos» (vv. 190-194).

At first glance, this deviation from conventional costume appears to support the notion of a sympathetic portrayal of the Moriscos as the oppressed, enslaved ethnic minority. But we must be cautious to avoid anachronism. The Enlightenment, with its mantra of liberté, egalité and fraternité, had not yet occurred. The abolition movement had not yet begun and the notion of cultural relativism would not appear for another two centuries. $17^{\text {th }}$ century Europe, and Catholic Spain in particular, was a place of nationalistic Catholicism, rigid ethnic and class distinctions, and xenophobia. In Madrid in the 1630s, the appearance of actors in Afro-Morisco costumes served to identify the characters, not as a oppressed minority worthy of sympathy, but as foreigners at the bottom of the social ladder, worthy of disdain and suspicion.

So, the Moriscos, having preconditioned the audience with their costumes to stand in judgment, begin to speak and act. Cadí, the leader of the group, speaks first and asks, «Están cerradas las puertas» (v. 1) and proceeds to say:

No entre nadie sin la seña

y prosígase la zambra.

Celebremos nuestro día, que es el viernes, a la usanza

de nuestra nación, sin que pueda esta gente cristiana, entre quien vivimos hoy presos en miseria tanta, calumniar ni reprender nuestras ceremonias. (vv. 3-12) 
The group then proceeds to sing a song that laments the end of Moorish dominance in Spain, celebrates the Moorish conquest of the peninsula in 711, and makes fun of the "españolilio altiva» who was hoodwinked and defeated by Musa ibn Nusair. And every stanza of the song is punctuated by a chorus of «iSu ley viva!», referring, of course, to the law of Allah.

Then, suddenly, the song is interrupted as the group is startled by a loud banging on the door. Cadí, the leader, concludes that

\author{
Sin duda cogernos tratan \\ en nuestras juntas; que, como \\ el Rey por editos manda \\ que se veden, la justicia, \\ viendo entrar en esta casa \\ hoy tantos moriscos, viene \\ siguiéndonos. (vv. 31-37)
}

Cadí orders everyone to hide their instruments and to tell whoever is at the door that they all just happened to drop by. One of the Moriscos compliments Cadí on the deception saying, "Muy bien lo trazas» (v. 45). Cadí then says, «Pues todos disimulemos» (v. 46) and orders Alcuzcuz to open the door. Alcuzcuz resists, fearing a beating from the authorities, but finally complies. In walks don Juan Malec, an elderly Morisco and member of the city council of Granada.

In summary, the Moriscos, have gathered to secretly engage in a Morisco celebration, the zambra, that Cadí points out is in direct violation of the edict of the King. They sing a song that glorifies the Islamic conquest of the peninsula, makes fun of old Christians, and is punctuated by a shout of "Long live the Law of Allah». Then, when the knock comes at the door, the group hides the evidence of their crime and together agrees to lie about why they are at Cadís house. The opening scene of the El Tuzani did not serve to generate sympathy for the Moriscos. On the contrary, the Moriscos are shown here as foreign, unassimilatable, duplicitous, and false Christians, who rebel against both Catholicism and the King. In other words, this portrayal of the Moriscos reaffirmed the old-Christian prejudices that justified the Expulsion.

Let's move on now to what happens when Alcuzcuz opens the door and don Juan Malec, enters the scene. Don Juan Malec, is a large- 
ly assimilated, elderly morisco of Moorish noble blood and a member of Granada's city council. Malec tells the Moriscos, who feared he had come to chastise them, that he has come from the City Council chambers where he has witnessed the official proclamation of Phillip II's prohibition of all forms of Morisco culture. He then narrates how he criticized the edict for demanding too much, too quickly, and proceeded to get into an argument with don Juan de Mendoza over the question of the equality or inequality of Moorish and old-Christian noble bloodlines. Critics have cited the altercation between Malec and Mendoza as indicating Calderón's sympathy for the Moriscos, because he is perceived as portraying the Morisco with dignity and the old Christian as arrogant, abusive and intransigent ${ }^{16}$.

Let's take a look at this altercation. Don Juan Malec, having narrated his objection to Phillip II's legislation, relates how he was challenged by don Juan de Mendoza, also a council member, whom he describes respectfully as a «deudo de la ilustre casa / del gran Marqués de Mondéjar. Don Juan de Mendoza suggests that Malec is defending the Moriscos because he is one himself, and that he is trying to forestall the punishment of a people who are «gente vil, humilde y baja» (v. 123).

Malec skirts the issue of the downtrodden state of the average Morisco, emphasizing that their current condition is product of the Fortune's capriciousness nature, and zeros in on the question of the status of Moriscos of noble Moorish blood. He tries argue that baptism into the Christian faith makes the Morisco nobility equal to old Christian nobility (vv. 136-143). Don Juan de Mendoza disagrees succinctly, saying simply that even a Moorish king is still a Moor (v. 146).

Don Juan Malec then relates how the debate degenerated into an argument, and admits that he probably went too far, saying something that provoked the younger Mendoza into hitting him with his own staff, thus offending his honor (vv. 160-164). The elder Morisco, who is too old to avenge the offence himself and has no sons to stand in for him, insists to the Moriscos who are listening that he has suffered this offence in defense of the honor of all Moriscos, and that, as such, they should take up arms to avenge the insult. Malec gives an impas-

16 Alcalá Zamora, 1981, pp. 347-348; Alcalá Zamora, 2000, pp. 299-300; Caso González, 1983, p. 397; Greer, 2006, p. 120; Otero Torres, 2000, pp. 196-197. 
sioned call to arms, the Moriscos enthusiastically agree, and secret plans for the rebellion begin (vv. 168-199).

Later in this scene, a small delegation arrives at don Juan Malec's house to attempt to mitigate the damage done. First they indicate that no real offence has been incurred, because the laws of the duel and personal honor do not apply in the council chambers, as is symbolized by the prohibition on personal weapons in the "cabildo» (vv. 414421). They suggest, however, that his perceived agravio may be dealt with peacefully through a marriage between don Juan Malec's daughter, doña Clara, and don Juan de Mendoza. Malec agrees to the marriage and but then says this in an aside: "Quiero usar de aqueste medio / mientras se empieza el motín» (vv. 500-501). In other words, while publicly agreeing to a peaceful solution, don Juan Malec will continue to plan the rebellion in secret.

The issue of the equality of bloodiness is revisited near the end of the first act, when the same delegation that visited don Juan Malec to propose the marriage solution arrives at don Juan de Mendoza's house to propose the same to him. Mendoza refuses the marriage saying:

ni sé que fuera decente

mezclar Mendozas con sangre

de Malec, pues no convienen

ni hacen buena consonancia

los Mendozas y Maleques.

When the Moriscos object to this, saying that Malec's ancestors were of kingly Moorish blood, Mendoza responds: «Pues los míos, sin ser reyes, / fueron más que reyes moros / porque fueron montañeses» (vv. 819-831). Again, the argument deteriorates into a confrontation between old Christians and Moriscos, who decide to take up arms in response to the affirmation that their new Christian blood is inferior to old Christian blood.

Now then, does this scene indicate sympathy for the Moriscos on Calderón's part and does it portray old-Christians as arrogant, abusive and intransigent as a number of critics have claimed? Let's consider the portrayal of old Christian. First, it is neither presumptuous nor arrogant for don Juan de Mendoza to suggest that don Juan de Malec is defending the Moriscos because he is a Morisco. Second, there is 
no reason to believe that a $17^{\text {th }}$ century audience, or Calderón himself, would have disagreed with don Juan de Mendoza's statements regarding the inherent inequality of new and old Christian bloodlines. Calderón himself passed the pruebas de sangre in 1636 in order to be accepted into the Order of Santiago. The equality that Malec desired was simply impossible for old Christians to accept. As a result, full assimilation was also impossible. The Moriscos no matter how prestigious their pedigree, would always be second best. This final barrier is unacceptable to Malec, the otherwise integrated, noble Morisco. As a result he decided to take up arms. Mendoza himself points out in the second act that his disagreement with don Juan Malec had a part in starting the rebellion (vv. 993-994). But this does not imply a criticism on Calderón's part of the old Christian viewpoint on pureza de sangre. From the old Christian perspective it can be argued that it is the Morisco who demonstrates arrogance and intransigence. The common Morisco is shown to resist integration with his persistent defiance of the Catholic faith and old Christian culture, while the integrated Morisco is arrogant in desiring what he plainly cannot have: equality with old Christians. We have no reason to believe that Calderón, much less the average $17^{\text {th }}$ century old Christian audience member, questioned the desirability of pureza de sangre any more than the average North American today questions the desirability of democracy.

But still, there is the fact that don Juan to Mendoza hits an older man, with his own staff. This was reprehensible in the seventeenth century. But this act is mitigated by the fact that don Juan de Mendoza lashed out, not at a fellow old Christian noble, but at a Morisco who challenged an accepted old-Christian belief. This is born out, later in first act when Mendoza commendably expresses regret for letting his anger get the better of him (v. 568), to which Garcés ${ }^{17}$ responds,

no por viejo el que es nuevo cristiano

piense que inmunidad el serlo goza

de atreverse a un González de Mendoza (vv. 571-573)

${ }^{17}$ Although Garcés is later shown to be of dubious moral character, at this point in the play, he is shown to be a loyal friend to Mendoza and a soldier under don Juan of Austria, recently returned from the much celebrated naval victory at Lepanto. 
If we add to this the fact that don Juan Malec himself has admitted to pushing the argument with Mendoza too far and provoking the younger man, the reprehensible nature of Mendoza's act is significantly softened. Mendoza acts impetuously when he strikes Malec, but he is neither arrogant nor intransigent by early seventeenth century criteria. By these standards Mendoza is simply defending the orthodox view with respect to pureza de sangre and loyally defending the King's edict in the face of criticism from a presumptuous Morisco.

Let's turn to the portrayal of don Juan Malec. On the positive side, Malec appears to be an integrated Morisco. As there is no reference to Malec's costume, other than the word "viejo» in the dramatis personae, we may assume that he is dressed as a Christian. He is also noble and a Veinticuatro, or town council member, of Granada, and he is a venerable «viejo». His integration is such that the common Moriscos view him some fear and suspicion. But for all this, he remains a Morisco. Malec is caught between cultures. He is feared by non integrated Moriscos and disdained by the old Christians.

Moving to the negative side of Malec's portrayal, as we have already established, Malec challenges the King's decree and makes statements regarding the equality of old and new Christian bloodlines that contradict the mainstream old Christian view on the matter. Malec's statements are eloquent to be sure, but that does not mean that he is meant to be perceived as speaking the truth or that he is being portrayed sympathetically, much less that his views are Calderón's views. One cannot arbitrarily choose an opinion expressed by given character and claim it is also the playwright's.

In El mágico prodigioso, for example, the Demonio's arguments to Cipriano are both eloquent and convincing, but that does not mean the Calderón or his audience accepted them as true or that they sympathized with the Demonio or his viewpoint. I am not suggesting that Malec is like the Demonio, but rather that when a character is eloquent in expressing his viewpoint, this does not imply that the playwright agrees with him. The character's statements have to be taken in their context. The relative orthodoxy of the opinions expressed have to be accounted for, as well as who is making the statements, and how that character's reception is conditioned by other statements and actions. 
It seems unlikely that an early $17^{\text {th }}$ century Spanish audience would $\mathrm{h}$ ave been predisposed to accept the unorthodox opinions of a Morisco over the orthodox opinions of an old-Christian noble related to the illustrious household of the Marquis of Mondéjar.

This is particularly true if we consider that Malec is shown to be duplicitous and conspiratorial. On the one hand he says he agrees that it is

ley justa y prevención santa

ir haciendo poco a poco

de la costumbre africana

olvido (vv. 105-108)

But when he is personally affronted and told he can never be equal to the old Christians nobility, regardless of how illustrious his Moorish ancestors may have been, he begins to secretly plot an armed rebellion against the crown. Then, after he publicly agrees to a peaceful resolution of the offense against him, he indicates in an aside to the audience that he will use the marriage of his daughter to his enemy as a cover to secretly continue with his plans for the rebellion. Malec thus confirms with his words and conduct the old Christian stereotype that Moriscos, even seemingly integrated ones, were deviant, untruthful, disloyal and conspiratorial. His unorthodox statements are thus conditioned by this negative characterization.

Now we must consider a pair Moriscos who's portrayal contradicts the negative portrayal for which I have thus far argued for. Even if we accept that in this play the rank and file Moriscos and Malec are portrayed in a negative light, it would be difficult to make this assertion for the don Álvaro Tuzaní and doña Clara Malec (aka «Maleca», the Moriscos who's tragic love story forms the nucleus of this play.

Don Álvaro and doña Clara are portrayed as paragons of honor and self sacrificing love, even beyond death. But again, we must put the play in its context. In this case it is the literary context that matters. The tragic story of these two Moriscos is a generic example of the sentimental stories of love and honor found in the romances fronterizos, and romances moriscos, and the novelas moriscas, such as the anonymous Abencerraje y la hermosa Jarifa, Las guerras civiles de Granada by Ginés Pérez de Hita, or the story of Ozmín y Daraja, found in Guzmán de Alfarache. In fact, Calderón closely modeled the tragic story of el 
Tuzaní and Maleca on the story of el Tuzaní and Maleca found in the second part of Ginés Pérez de Hita's Guerras civiles de Granada.

But, as history bears out, the popularity of this sentimental, idealized, literary Moor in the $16^{\text {th }}$ and $17^{\text {th }}$ centuries, did not imply an acceptance of sympathy for the Moriscos in real life. On the contrary, the rise of the novela morisca coincides with intensified repression against the minority ${ }^{18}$. As Domínguez Ortiz points out, although Moorish literature appears to display sympathy towards the minority,

Guardémonos, sin embargo, de sacar consecuencias excesivas de esta maurofilia literaria tan acusada en nuestro Siglo de Oro. Entre los moros idealizados de la Edad Media y los abatidos moros del xvi mediaba todo el abismo que existe entre el idealismo puro y el sórdida realidad. El mismo fray Luis de León, que alababa al «sabio moro» sentía una irrefrenable hostilidad hacia los moriscos ${ }^{19}$.

Thus we must be careful not to assume that Calderón's use of the trope of the sentimental Morisco implies a sympathy for the Moriscos as a people. On the contrary, the positive aspects of this literary sentimentality must be weighed against the negative stereotypes employed to characterize the other Moriscos of this play. And the result is ambiguous: on the one hand we have the idealized, sentimental and honorable Morisco, on the other hand we are presented with the Morisco as unassimilatable, untrustworthy, deceptive and conspiratorial.

While much more evidence may be brought to bear, the examples given should suffice to at least cast doubt on readings of this play that portray Calderón as both sympathetic to the Moriscos as an oppressed minority group and critical of old Christian thinking regarding the minority. Calderón, in my view, does not question the rightness of the project of ethnocide, of forced assimilation against the Moriscos. But he does appear to place part of the blame for its failure Phillip II's fanatical legislation, which forced a confrontation and arguably derailed the slow integration process. We may fairly attribute this perspective to Calderón because it is expressed by apposing sides. Don Juan Malec asserts that

19 Domínguez Ortiz, 1978, p. 154. 
aunque era

ley justa y prevención santa

ir haciendo poco a poco

de la costumbre africana

olvido, no era razón

que fuese con furia tanta;

y así, que se procediese

en el caso con templanza,

porque la violencia sobra

donde la costumbre falta. (vv. 102-113)

And Mendoza, his direct opponent, expresses a similar opinion, when he refers to «las premáticas severas / que tanto los apretaron» (vv. 987-988) and indicates that

\author{
ya oprimidos \\ de ver cuánto los aprietan \\ órdenes que cada día \\ aquí de la corte llegan, \\ los desesperó de suerte \\ que amotinarse conciertan (vv. 1000-1006)
}

Calderón, as we have observed, also connects the outbreak of the rebellion with the tension caused by the impossibility of equality between new and old Christian bloodlines, which served as an permanent barrier to assimilation. This may be taken as a criticism of the politics of pureza de sangre. On the other hand, Calderón may have agreed that this barrier protected cultural territory that could not in good, old Christian conscience be conceded. The play may be read to imply that it was the Moriscos who brought about their own downfall and eventual expulsion by means of what is portrayed as their duplicitous, conspiratorial nature, their intransigence with respect to Catholicism and the unacceptable desire among high born Morisco nobles to be counted as equals with old Christians.

The final scene of the play may be interpreted as supporting this latter reading. The play's ending is an alternate version of history. Perhaps history as it should have been, rather than as it was. At the end of the play, which is end of the rebellion, instead of being punished with relocation throughout Castile, the Moriscos, represented by 
doña Isabel, wife of the dead Morisco king, beg forgiveness for their rebelliousness, committing themselves fully and humbly to the Church and to the King. And don Juan de Austria, the King's representative, forgives them. Calderón may be suggesting in his ending that only the total submission and unconditional assimilation of the Moriscos could have generated a different history and prevented the Expulsion. 


\section{BIBLIOGRAPHY}

Alcalá Zamora, J., "Individuo e historia en la estructura teatral de El Tuzaní de la Alpujarra», en Calderón: Actas del congreso internacional sobre Calderón y el teatro español del Siglo de Oro, ed. L. García Lorenzo, Madrid, CSIC, 1981, vol. I, pp. 343-363.

- Estudios Calderonianos, ed. E. Ruano, Madrid, Real Academia de la Historia, 2000.

Anonymous, El Abencerraje y la hermosa Jarifa, ed. V. Lama y E. Peral Vega, Madrid, Castalia, 2000.

Calderón de la Barca, P., Comedias. Vol. XVIII Novena parte de comedias (Madrid 1691), ed. D. W. Cruickshank and J. E. Varey, Westmead and London, Gregg International and Tamesis, 1973.

- El Tuzaní de la Alpujarra o Amar después de la muerte, ed. B. Devos, Ottawa, The University of Ottawa, 2007.

Caso GonzÁlez, J. M., «Calderón y los moriscos de las Alpujarras», en Calderón: Actas del congreso internacional sobre Calderón y el teatro español del Siglo de Oro, ed. L. García Lorenzo, Madrid, CSIC, 1983, vol. I, pp. 393402.

Devos, B., introducción a El Tuzaní de la Alpujarra o Amar después de la muerte: edición crítica con introducción y notas, Ottawa, The University of Ottawa, 2007.

Domínguez Ortiz, A., Historia de los moriscos: vida y tragedia de una minoría, Madrid, Biblioteca de la Revista de Occidente, 1978.

ESQUERdo, V., «Indumentaria con que los cómicos representaban en el siglo XVII», Boletín de la Real Academia Española, 58, 1978, pp. 447-544.

Greer, M. R., "The Politics of Memory in El Tuzaní de la Alpujarra», en Rhetoric and Reality in Early Modern Spain, ed. R. J. Pym, London, Tamesis, 2006, pp. 113-130.

Otero Torres, D., "Amor y silencio: ecos del discurso minoritario en Amar después de la muerte», en El escritor y la Escena VII: Estudios sobre teatro español y novohispano de los Siglos de Oro, ed. Y. Campbell, Ciudad Juárez, Universidad Autónoma de Ciudad Juárez, 2000, pp. 195-203.

Parker, A. A., The mind and art of Calderón: essays on the Comedias, ed. D. Kong, Cambridge, Cambridge University Press, 1988.

Rodríguez Cuadros, E., «El hato de la risa: identidad y ridículo en el vestuario del teatro breve del Siglo de Oro», en El vestuario en el teatro español del Siglo de Oro, ed. M. de los Reyes Peña, Cuadernos de Teatro Clásico, Madrid, Compañía de Teatro Clásico, 13-14, 2000, pp. 109-137.

Ruano de la Haza, J. M., La puesta en escena en los teatros comerciales del Siglo de Oro, Madrid, Castalia, 2000. 
Ulloa Cisneros, L. y E. Camps Cazorla, Historia de España, vol. IV: La Casa de Austria (Siglos XVI y XVII), Barcelona, Instituto Gallach, 1979.

Wilson, M., "Si África llora, España no ríe”: A Study of Calderón’s Amar después de la muerte in Relation to its Source», Bulletin of Hispanic Studies, 61, 1984, pp. 419-425. 
